\title{
PRAWNOAUTORSKA OCHRONA PROGRAMÓW KOMPUTEROWYCH - REGULACJA POLSKA I JEJ UNIJNY WZORZEC W ŚWIETLE ORZECZNICTWA TRYBUNALU SPRAWIEDLIWOŚCI
}

\section{RYS HISTORYCZNY}

Programy komputerowe zostały po raz pierwszy wymienione jako przedmiot prawa autorskiego w 1980 r. w Stanach Zjednoczonych. W znowelizowanym wówczas federalnym prawie autorskim został wymieniony „program komputerowy", który zdefiniowano jako zestaw rozkazów lub instrukcji przeznaczonych do wykonywania bezpośrednio lub pośrednio w komputerze w celu osiagnięcia określonego rezultatu ${ }^{1}$.

W państwach członkowskich Europejskiej Wspólnoty Gospodarczej prawnoautorska ochrona programów komputerowych została zharmonizowana na podstawie dyrektywy Rady 91/250/EWG z 14 maja $1991 \mathrm{r}$. w sprawie prawnej ochrony programów komputerowych ${ }^{2}$ (obecnie: dyrektywa 2009/24/WE - zob. niżej).

Powyższe decyzje prawodawcze związane były z odrzuceniem, co do zasady, patentowej ochrony programów komputerowych ${ }^{3}$, a także modelu ochrony sui generis przygotowanego przez Światową Organizację Własności Intelektualnej (WIPO) ${ }^{4}$. Jednym z głównych motywów włączenia programów komputerowych w ramy prawa autorskiego było dążenie do objęcia ich Konwencją berneńską o ochronie dzieł literackich i artystycznych ${ }^{5}$ i przewidzianą w niej zasadą asymilacji, zapewniająca ochronę we wszystkich państwach stronach tej Konwencji.

W związku z sytuacją w Polsce należy uwzględnić fakt zawarcia w $1991 \mathrm{r}$. Układu o stowarzyszeniu ze Wspólnotami Europejskimi i ich państwami człon-

1 Title 17 of the U.S. Code, $\S 101$ (,A "computer program" is a set of statements or instructions to be used directly or indirectly in a computer in order to bring about a certain result").

${ }^{2}$ Dz. Urz. WE L 122 z 17 maja 1991 r., s. 42 i n.

${ }^{3}$ Odnośnie do ówczesnej sytuacji w Stanach Zjednoczonych zob. wyrok Sądu Najwyższego USA z 1972 r. w sprawie Gottschalk v. Benson (409 U.S. 63). W Europie takie podejście znalazło odzwierciedlenie w Konwencji o udzielaniu patentów europejskich z 1973 r. (Dz. U. 2004, Nr 79, poz. 737 ze zm.), w której uznano, że programy komputerowe nie są wynalazkami (zob. art. 52 ust. 2 i 3 ).

${ }^{4}$ Zob. The WIPO Model Provisions on the Protection of Computer Software, „European Intellectual Property Review" (EIPR) 1979, nr 2, s. 36.

${ }^{5}$ Konwencja berneńska o ochronie dzieł literackich i artystycznych z 1886 r., obecnie obowiązująca w Akcie paryskim z 1971 r., Dz. U. 1990, Nr 82, poz. 474. 
kowskimi ${ }^{6}$, w którym kraj nasz zobowiązał się do zbliżenia swego systemu ochrony praw własności intelektualnej do standardów obowiązujących w EWG (art. 66 ust. 2). Wcześniej, 21 marca 1990 r., Polska zawarła ze Stanami Zjednoczonymi Traktat o stosunkach handlowych i gospodarczych ${ }^{7}$, który nałożył wiele kosztownych zobowiązań, także w dziedzinie własności intelektualnej. W szczególności Polska zobowiązała się do rozciagnnięcia ochrony praw autorskich na programy komputerowe ,jako dzieła literackie” (art. IV).

Wspomniane zobowiązania międzynarodowe (Układ stowarzyszeniowy oraz Traktat polsko-amerykański) spowodowały, że w ówcześnie przygotowywanej ustawie o prawie autorskim, mającej zastapić ustawę z $1952 \mathrm{r}^{8}$, po raz pierwszy uregulowano expressis verbis ochronę programów komputerowych. W związku z prawem autorskim z 1952 r. warto zauważyć, że mimo iż ustawa ta nie wspominała o programach komputerowych, to jednak w okresie jej obowiązywania przyjmowano, że program komputerowy może spełniać przesłanki utworu i podlegać ochronie prawnoautorskiej9. Jednak, zdaniem Stanisława Sołtysińskiego, rozwiązaniem optymalnym miało być stworzenie specjalnego reżimu ochrony. Autor nie przesądzał negatywnie kwestii uznania programu za przedmiot prawa autorskiego, jednakże zwracał uwagę na niedostosowanie rozwiązań tego działu prawa do tak specyficznej kategorii dóbr intelektualnych. Prezentując model odrębnej ochrony programów, autor był zdania, że model ten mógł obowiązywać równolegle ze zmodyfikowanym systemem ochrony prawnoautorskiej ${ }^{10}$.

Ustawa z 4 lutego 1994 r. o prawie autorskim i prawach pokrewnych ${ }^{11}$ ustanowiła ochronę programów komputerowych na poziomie niemal dokładnie odpowiadającym rozwiązaniom przewidzianym w dyrektywie 91/250/EWG. Kilka nieścisłości usunięto nowelizacją dokonaną ustawą z 9 czerwca 2000 r. ${ }^{12}$, a więc jeszcze przed przystapieniem do Unii Europejskiej. Zaznaczyć należy, że sprawa

${ }^{6}$ Tzw. Układ europejski, Dz. U. 1994, Nr 11, poz. 38 ze zm.

${ }^{7}$ Dz. U. 1994, Nr 97, poz. 467 i 468 (Traktat wszedł w życie 6 sierpnia 1994 r.). W przeciwieństwie do umów handlowych z innymi państwami trzecimi, które w związku z przystapieniem do Unii Europejskiej zostały przez Polskę wypowiedziane, Traktat polsko-amerykański obowiazuje nadal. 12 stycznia 2004 r. został w Brukseli podpisany Protokół dodatkowy do Traktatu (Dz. U. 2005, Nr 3, poz. 14), którego sporządzenie było konieczne ze względu na wymagania prawa unijnego.

${ }^{8}$ Ustawa z 10 lipca 1952 r. o prawie autorskim, Dz. U. Nr 34, poz. 234 ze zm.

${ }^{9}$ Zob. wyrok SA w Gdańsku z 29 stycznia 1993 r., AGCr 369/92, „Orzecznictwo Sądów Polskich” 1993, z. 11, poz. 216 z glosą J. Barty i R. Markiewicza. W orzeczeniu tym stwierdzono, że oprogramowanie komputerowe może być traktowane jako utwór o charakterze naukowym lub literackim.

${ }^{10}$ Zob. S. Sołtysiński, Ochrona prawna programów komputerowych, w: Problemy kodyfikacji prawa cywilnego. Księa pamiatkowa ku czci Profesora Zbigniewa Radwańskiego, Poznań 1990, s. 449 i n.

${ }^{11}$ Pierwotna wersja ustawy została ogłoszona w: Dz. U. 1994, Nr 24, poz. 83. Obecnie ustawa obowiązuje w tekście jednolitym ogłoszonym w: Dz. U. 2006, Nr 90, poz. 631 ze zm. (dalej jako: pr.aut.) Na temat przepisów tej ustawy regulujących ochronę programów komputerowych zob. np. A. Nowicka, Prawnoautorska i patentowa ochrona programów komputerowych, Warszawa 1995; J. Barta, R. Markiewicz, w: J. Barta et al., Prawo autorskie i prawa pokrewne. Komentarz, wyd. 5, Warszawa 2011; J. Barta, R. Markiewicz, Prawo autorskie, Warszawa 2013.

${ }^{12}$ Dz. U. Nr 53, poz. 637. 
ochrony programów komputerowych była w ówczesnej EWG przedmiotem gwałtownych dyskusji i sporów, a rozwiązania przyjęte w dyrektywie 91/250/EWG mogą być uznane za przejaw rozsądnego kompromisu. Udało się bowiem stworzyć takie mechanizmy respektowania podstawowych funkcji prawa autorskiego, które w należytej mierze uwzględniają nie tylko interesy podmiotów, którym przysługuja prawa autorskie, lecz także interesy konkurentów oraz legalnych użytkowników.

Dyrektywa 91/250/EWG została uchylona i obecnie obowiązuje jej ujednolicona (skodyfikowana) wersja zawarta w dyrektywie Parlamentu Europejskiego i Rady 2009/24/WE z 23 kwietnia 2009 r. w sprawie ochrony prawnej programów komputerowych ${ }^{13}$. Teksty obu dyrektyw sa niemal identyczne. Nowa dyrektywa obejmuje tylko jedną zmianę dokonaną dyrektywą Rady 93/98/EWG z 29 października $1993 \mathrm{r}$. w sprawie harmonizacji czasu trwania ochrony praw autorskich i niektórych praw pokrewnych ${ }^{14}$, dotyczaca art. 11 ust. 1 dyrektywy 91/250/EWG. Oprócz tej zmiany wprowadzono kilka innych modyfikacji, np. skreślono motyw 25 preambuły pierwotnej dyrektywy, a w art. 1 dodano ust. 4, który stanowi, że przepisy nowej dyrektywy stosuje się także do programów stworzonych przed 1 stycznia 1993 r., bez uszczebku dla jakichkolwiek aktów przyjętych i praw nabytych przed tą data.

Wśród międzynarodowych uwarunkowań prawnoautorskiej ochrony programów komputerowych należy również uwzględnić Porozumienie w sprawie handlowych aspektów praw własności intelektualnej (TRIPS) ${ }^{15}$ oraz Traktat WIPO o prawie autorskim (WCT) ${ }^{16}$. Jak stanowi art. 10 ust. 1 TRIPS: „programy komputerowe, zarówno w kodzie źródłowym jak i przedmiotowym będą chronione jak dzieła literackie na podstawie Konwencji berneńskiej (1971)" ${ }^{\prime 1}$. Z kolei art. 4 WCT przewiduje, że „programy komputerowe są chronione jak utwory literackie w rozumieniu artykułu 2 Konwencji berneńskiej. Ochrona ta odnosi się do programów komputerowych niezależnie od sposobu lub formy wyrażenia".

\section{PROGRAM KOMPUTEROWY JAKO UTWÓR W POLSKIM PRAWIE AUTORSKIM; ZAKRES PRZEDMIOTOWY OCHRONY}

Jako przedmiot prawa autorskiego programy komputerowe zostały wymienione w grupie utworów „wyrażonych słowem, symbolami matematycznymi, znakami graficznymi” (art. 1 ust. 2 pkt 1 pr.aut.), obok takich utworów, jak

${ }^{13}$ Dz. Urz. UE L 111 z 5 maja 2009 r., s. 16.

${ }^{14}$ Dz. Urz. WE L 290 z 14 listopada 1993 r. Obecnie chodzi o skodyfikowaną wersję zawarta w dyrektywie 2006/116/WE z 12 grudnia 2006 r. w sprawie czasu ochrony prawa autorskiego i niektórych praw pokrewnych, Dz. Urz. UE L 372 z 27 grudnia 2006 r.

${ }_{15}$ Porozumienie TRIPS, stanowiące załącznik 1C do Porozumienia ustanawiającego Światową Organizację Handlu, jest ogłoszone w: Dz. U. 1996, Nr 32, poz. 143 - załącznik.

${ }^{16}$ Dz. U. 2005, Nr 3, poz. 12. W stosunku do Polski Traktat wszedł w życie 23 marca 2004 r., a w stosunku do Unii Europejskiej - 14 marca 2010 r. (zob. Dz. Urz. UE L 32 z 4 lutego 2010 r., s. 1).

${ }^{17}$ Chodzi o Akt paryski z 1971 r. Konwencji berneńskiej (zob. wyżej przyp. 5). 
literackie, publicystyczne, naukowe i kartograficzne. Zwraca uwage fakt, że podobnie jak w dyrektywie 2009/24/WE (poprzednio: 91/250/EWG) - również $\mathrm{w}$ polskiej ustawie nie zamieszczono definicji programu komputerowego. Jednym z istotnych motywów tego pominięcia było ryzyko zdezaktualizowania się definicji w następstwie postępu technicznego ${ }^{18}$.

Zasadnicza regulacja prawnoautorskiego statusu omawianej kategorii utworów jest zawarta w rozdziale 7 ustawy, zawierajacym przepisy szczególne dotyczące programów komputerowych (art. 74-7722). Jak stanowi art. 74 ust. 1 pr.aut.: „programy komputerowe podlegaja ochronie jak utwory literackie, o ile przepisy niniejszego rozdziału nie stanowią inaczej”.

W związku z powyższym postanowieniem należy uwzględnić definicję utworu (art. 1 ust. 1 pr.aut.), zgodnie z która „przedmiotem prawa autorskiego jest każdy przejaw działalności twórczej o indywidualnym charakterze, ustalony w jakiejkolwiek postaci, niezależnie od wartości, przeznaczenia i sposobu wyrażenia (utwór)". W kontekście ogólnym należy mieć również na uwadze postanowienie, według którego „utwór jest przedmiotem prawa autorskiego od chwili ustalenia, chociażby miał postać nieukończona” (art. 1 ust. 3 pr.aut.), a także zasadę, że „ochrona przysługuje twórcy niezależnie od spełnienia jakichkolwiek formalności” (art. 1 ust. 4 pr.aut.).

Zakres przedmiotowy ochrony jest określony w art. 74 ust. 2 pr.aut., zgodnie z którym ochrona przyznana programowi komputerowemu obejmuje wszystkie formy jego wyrażenia, natomiast idee i zasady będące podstawą jakiegokolwiek elementu programu komputerowego, w tym podstawą łączy, nie podlegają ochronie ${ }^{19}$. Zasada, według której ochrona prawnoautorska obejmuje wyłącznie sposób (formę) wyrażenia ${ }^{20}$, została następnie wyrażona expressis verbis także w odniesieniu do innych utworów. Wyrażenie tej zasady, która również w prawie polskim nigdy nie budziła wątpliwości, nastapiło w celu odzwierciedlenia art. 9 ust. 2 TRIPS $^{21}$. Dodany ustawą nowelizująca z 28 października $2002 \mathrm{r.}^{22}$ przepis art. 1 ust. $2^{1}$ pr.aut. stanowi, że ochrona objęty może być wyłącznie sposób wyrażenia; nie są objęte ochroną odkrycia, idee, procedury, metody i zasady działania oraz koncepcje matematyczne.

$\mathrm{Na}$ temat stosowania zasady wyrażonej w art. 74 ust. 2 pr.aut. wypowiedział się Sąd Apelacyjny w Poznaniu w wyroku z 4 stycznia 1995 r. ${ }^{23}$, w którym trafnie

\footnotetext{
${ }_{18} \mathrm{Na}$ temat pominięcia definicji programu komputerowego zob. szerzej opinię rzecznika generalnego Y. Bota z 14 października 2010 r. w sprawie C-393/09 - Bezpečnostni softwarová asociace (poniżej), zwłaszcza pkt 45-48 opinii. Zob. też projekt dyrektywy 91/250/EWG przedstawiony przez Komisję Europejską 5 stycznia 1989 r., COM (88), 816, Dz. Urz. WE C 91 z 12 kwietnia 1989 r., s. 4 i n.

19 Dla porównania zob. art. 1 ust. 2 dyrektywy 2009/24/WE, który stanowi: Zgodnie z niniejszą dyrektywą ochronie podlega każda forma wyrażenia (expression) programu komputerowego. Koncepcje (ideas) i zasady (principles), na których opierają się wszystkie elementy programu komputerowego, włącznie z tymi, na których opierają się ich interfejsy (interfaces), nie podlegaja ochronie prawa autorskiego na podstawie niniejszej dyrektywy.

${ }_{20}$ Zasada ta odzwierciedla dychotomię idea/expression (Form/Inhalt).

21 Art. 9 ust. 2 TRIPS stanowi: „Ochrona w zakresie praw autorskich dotyczy wyłącznie sposobu wyrażania, a nie idei, procedur, metod działania lub koncepcji matematycznych”.

22 Dz. U. Nr 197, poz. 1662.

${ }^{23}$ I ACr 422/94, Lex, nr 62604.
} 
stwierdził, że podobieństwo w zakresie samej funkcji programów nie może być dostateczną podstawą naruszenia prawa autorskiego. Zdaniem sądu, aby doszło do naruszenia prawa autorskiego, podobieństwo porównywanych utworów musi być innego rodzaju, niż podobieństwo wynikajace ze sposobu przedstawienia zadania oraz kontynuacji i rozwijania ogólnie znanych danych.

W orzecznictwie Trybunału Sprawiedliwości Unii Europejskiej (TS, Trybunał ${ }^{24}$ problemy związane z określeniem zakresu ochrony przyznanej programom komputerowym były przedmiotem rozstrzygnięć zawartych w dwóch orzeczeniach, tj. w wyroku z 22 grudnia 2010 r. w sprawie C-393/09 - Bezpečnostni softwarová asociace - Svaz softwarové ochrany przeciwko Ministerstvu kultury ${ }^{25}$ oraz w wyroku z 2 maja 2012 r. w sprawie C-406/10 - SAS Institute Inc. przeciwko Word Programming Ltd ${ }^{26}$.

W pierwszym z orzeczeń (C-393/09 - Bezpečnostni softwarová asociace) Trybunał uznał, że graficzny interfejs użytkownika (a graphic user interface) nie stanowi formy wyrażenia programu komputerowego w rozumieniu art. 1 ust. 2 dyrektywy 91/250/EWG i nie może korzystać z ochrony przyznanej w prawie autorskim programom komputerowym na podstawie tej dyrektywy. Niemniej, zdaniem Trybunału, jeśli taki interfejs stanowi wyraz własnej twórczości intelektualnej jego autora, może on korzystać z przewidzianej w prawie autorskim ochrony jako utwór, zgodnie z dyrektywą 2001/29/WE Parlamentu Europejskiego i Rady z 22 maja 2001 r. w sprawie harmonizacji niektórych aspektów praw autorskich i pokrewnych w społeczeństwie informacyjnym ${ }^{27}$. Ponadto Trybunał wypowiedział się na temat transmisji telewizyjnej graficznego interfejsu użytkownika, stwierdzając, że nie stanowi ona publicznego udostępniania utworu chronionego prawem autorskim w rozumieniu art. 3 ust. 1 dyrektywy 2001/29/WE.

W drugim ze wspomnianych orzeczeń dotyczących wykładni art. 1 ust. 2 dyrektywy 91/250/EWG (C-406/10 - SAS Institute Inc. przeciwko Word Programming Ltd.) Trybunał stwierdził, że ani zbiór funkcji programu komputerowego, ani język programowania i format plików danych używanych w ramach programu komputerowego w celu korzystania z pewnych jego funkcji nie stanowia formy wyrażenia tego programu i nie podlegaja $\mathrm{z}$ tego tytułu ochronie przyznawanej programom komputerowym przez prawo autorskie

\footnotetext{
${ }^{24}$ Wymienione niżej wyroki TS zostały wydane w odpowiedzi na wnioski o wydanie orzeczeń w trybie prejudycjalnym, skierowane przez sądy krajowe zgodnie z art. 267 TfUE. Pełna treść wyroków oraz opinii rzeczników generalnych jest dostępna na: www.curia.europa.eu. Pytania prejudycjalne oraz tezy wyroków są publikowane w serii C „Dziennka Urzędowego UE” (niżej wskazane są dane dotyczące tych publikacji).

25 Dz. Urz. UE C 63 z 26 lutego 2011 r., s. 8. Wyrok został wydany w odpowiedzi na pytania prejudycjalne Sądu Najwyższego Republiki Czeskiej złożone w TS 5 października 2009 r. (Dz. Urz. UE C 11 z 16 stycznia 2010 r., s. 14). Zob. też opinię rzecznika generalnego Y. Bota z 14 października $2010 \mathrm{r}$.

${ }^{26}$ Dz. Urz. UE C 174 z 16 czerwca 2012 r., s. 5. Wyrok został wydany w odpowiedzi na pytania prejudycjalne sądu angielskiego złożone w TS 11 sierpnia 2010 r. (Dz. Urz. UE C 346 z 18 grudnia 2010 r., s. 26). Zob. też opinię rzecznika generalnego Y. Bota z 29 listopada 2011 r. Stan faktyczny sprawy, w której wystapiły pytania prejudycjalne, został przedstawiony w orzeczeniu High Court of Justice (Chancery Division) z 23 lipca 2010 r., [2010] EWHC 1829 (Ch) (www.bailii.org/).

27 Dz. Urz. WE L 167 z 22 czerwca 2001 r.
} 
w rozumieniu tej dyrektywy ${ }^{28}$. Na szczególną uwagę zasługuje sposób uzasadnienia tezy, że zbiór funkcji programu komputerowego (functionality of a computer program) nie stanowi formy wyrażenia programu, a zatem nie podlega ochronie prawnoautorskiej. Podzielajac stanowisko wyrażone przez rzecznika generalnego Y. Bota ${ }^{29}$, Trybunał wskazał, że przyjęcie tezy, iż zbiór funkcji programu komputerowego mógłby być chroniony prawem autorskim, oznaczałoby umożliwienie monopolizowania koncepcji (ideas) kosztem postępu technicznego i rozwoju przemysłowego (pkt 40 uzasadnienia wyroku). Trybunał powołał się również na pkt 3.7 uzasadnienia projektu dyrektywy 91/250/EWG, w którym wskazano, że podstawową zaleta ochrony programów komputerowych przez prawo autorskie jest objęcie ochroną wyłącznie indywidualnego wyrażenia utworu (individual expression of the work) i pozostawienie innym autorom zamierzonej swobody tworzenia podobnych, a nawet identycznych programów, o ile nie są one wynikiem powielenia (pkt 41 uzasadnienia wyroku).

Warto dodać, że w omawianym wyroku w sprawie C-406/10 - SAS Institute Inc. Trybunał sformułował ponadto tezę dotyczącą wykładni art. 2 lit. a dyrektywy 2001/29/WE w sprawie harmonizacji niektórych aspektów praw autorskich i pokrewnych w społeczeństwie informacyjnym. Zdaniem Trybunału przepis ten należy interpretować $\mathrm{w}$ ten sposób, że powielenie w programie komputerowym lub w podręczniku użytkownika tego programu niektórych elementów opisanych w podręczniku użytkownika innego programu komputerowego chronionego prawem autorskim może stanowić naruszenie prawa autorskiego przysługującego do tego podręcznika, jeśli - czego sprawdzenie należy do sądu krajowego - to powielenie stanowi wyraz własnej twórczości intelektualnej autora podręcznika użytkownika programu komputerowego chronionego prawem autorskim. Sposób zredagowania tej tezy budzi wattpliwość dotyczącą sformułowania: ,jeśli [...] to powielenie stanowi wyraz własnej twórczości intelektualnej autora podręcznika użytkownika programu komputerowego chronionego prawem autorskim" (,if [...] that reproduction constitutes the expression of the intellectual creation of the author of the user manual for the computer program protected by copyright"). Nie sposób bowiem przyjąć, aby „powielenie” (ściślej: „Zwielokrotnienie”, ang. reproduction) mogło stanowić „wyraz własnej twórczości intelektualnej”. Poprawnie kwestia ta została ujęta $\mathrm{w}$ wydanej $\mathrm{w}$ tej sprawie opinii rzecznika generalnego ${ }^{30}$, w której w pkt 4 proponowanej konkluzji rzecznik stwierdził: „Arty-

${ }^{28}$ Teza ta stanowi odpowiedź na następujące pytanie prejudycjalne: Czy w razie gdy program komputerowy (zwany dalej „pierwszym programem”) jest chroniony prawem autorskim jako dzieło literackie, art. 1 ust. 2 należy interpretować w ten sposób, że nie stanowi naruszenia praw autorskich do pierwszego programu stworzenie przez konkurenta podmiotu praw autorskich - bez dostępu do kodu źródłowego pierwszego programu, ani bezpośrednio, ani za pomocą procedury takiej jak dekompilacja kodu przedmiotowego - innego programu (zwanego dalej „drugim programem") kopiującego funkcje pierwszego programu?

${ }^{29}$ Zob. pkt 57 opinii z 29 listopada 2011 r. Rzecznik generalny określił funkcje programu komputerowego jako „zespół możliwości, jakie oferuje system informatyczny, i działania właściwe dla tego programu. Innymi słowy, funkcja programu komputerowego jest usługa, której oczekuje od niego użytkownik" (zob. pkt 52 opinii).

${ }^{30}$ Opinia rzecznika generalnego Y. Bota z 29 listopada 2011 r. w sprawie C-406/10. 
kuł 2 lit. a dyrektywy 2001/29/WE [...] należy interpretować w ten sposób, że powielanie $\mathrm{w}$ programie komputerowym lub w podręczniku niektórych elementów opisanych w podręczniku do innego programu komputerowego może stanowić naruszenie prawa autorskiego do tego podręcznika, jeżeli - co powinien stwierdzić sąd krajowy - elementy w ten sposób zwielokrotnione stanowią wyrażenie własnej twórczości intelektualnej ich autora” (,[...] if [...] the elements reproduced in this way are the expression of their author's own intellectual creation").

\section{PRACODAWCA JAKO PODMIOT AUTORSKICH PRAW MAJĄTKOWYCH DO PROGRAMU KOMPUTEROWEGO}

Stosownie do art. 74 ust. 3 pr.aut. prawa majątkowe do programu komputerowego stworzonego przez pracownika w wyniku wykonywania obowiązków ze stosunku pracy przysługują pracodawcy, o ile umowa nie stanowi inaczej ${ }^{31}$. Regulacja ta odzwierciedla postanowienie art. 2 ust. 3 dyrektywy 2009/24/WE ${ }^{32}$ i ma charakter szczególny nie tylko w stosunku do zasady wyrażonej w art. 8 pr.aut., według której podmiotem prawa autorskiego jest twórca, lecz również w stosunku do ogólnej regulacji utworów pracowniczych zawartej w art. 12 pr.aut. ${ }^{33}$ Zgodnie $\mathrm{z}$ ostatnio wymienionym przepisem, jeżeli ustawa lub umowa o pracę nie stanowią inaczej, pracodawca, którego pracownik stworzył utwór w wyniku wykonywania obowiązków ze stosunku pracy, nabywa $\mathrm{z}$ chwilą przyjęcia utworu autorskie prawa majątkowe $\mathrm{w}$ granicach wynikających z celu umowy o pracę i zgodnego zamiaru stron. W drodze wyjątku od tej ogólnej regulacji w art. 74 ust. 3 pr.aut. postanowiono, że - o ile umowa nie stanowi inaczej - pracodawca nabywa, i to w sposób pierwotny z mocy tego przepisu (ex lege), całość praw majątkowych do programu komputerowego stworzonego przez pracownika w wyniku wykonywania obowiązków ze stosunku pracy. Zwrot „o ile umowa nie stanowi inaczej” oznacza, że przepis ma charakter względnie wiążący (ius dispositivum), a zatem strony mogą odmiennie uregulować tę kwestię i mogą np. postanowić, że autorskie prawa majątkowe do programu komputerowego będą należały wspólnie do pracodawcy i pracownika albo że prawa te będą przysługiwać pracownikowi.

${ }^{31}$ Zob. np. wyroki SN z 9 stycznia 2001 r. (I PKN 493/00, OSNP 2002, nr 17, poz. 407) i z 16 maja 2001 r. (I PKN 389/00, OSNP 2003, nr 5, poz. 119) oraz wyrok SA w Poznaniu z 11 lipca 2013 r. (I ACa 600/13).

${ }^{32}$ Przepis ten stanowi, że jeśli program komputerowy został stworzony przez pracownika w ramach wykonywania obowiązków służbowych lub w wykonywaniu poleceń pracodawcy, pracodawca jest wyłącznie uprawniony do wykorzystywania wszystkich praw majątkowych dotyczących programu tak stworzonego, chyba że umowa stanowi inaczej.

33 Zob. szerzej A. Nowicka, Podmiot prawa autorskiego, w: System prawa autorskiego, t. 13: Prawo autorskie, red. J. Barta, wyd. 3, Warszawa 2013, s. 79 i n. 


\section{TREŚĆ AUTORSKICH PRAW MAJAৃTKOWYCH DO PROGRAMU KOMPUTEROWEGO}

Jakkolwiek w przepisach ogólnych autorskie prawa majątkowe zostały określone jako „wyłączne prawo do korzystania z utworu i rozporządzania nim na wszystkich polach eksploatacji oraz do wynagrodzenia za korzystanie z utworu" (art. 17 pr.aut.), to jednak w odniesieniu do programów komputerowych zestaw wyłącznych uprawnień majątkowych określony jest - wzorem dyrektywy 91/250/EWG (obecnie: 2009/24/WE) - w sposób szczególny. Jak stanowi art. 74 ust. 4 pr.aut., autorskie prawa majattkowe do programu komputerowego, z zastrzeżeniem przepisów art. 75 ust. 2 i 3, obejmuja prawo do: 1) trwałego lub czasowego zwielokrotnienia programu komputerowego w całości lub w części jakimikolwiek środkami i w jakiejkolwiek formie; w zakresie, w którym dla wprowadzania, wyświetlania, stosowania, przekazywania i przechowywania programu komputerowego niezbędne jest jego zwielokrotnienie, czynności te wymagaja zgody uprawnionego; 2) tłumaczenia, przystosowywania, zmiany układu lub jakichkolwiek innych zmian w programie komputerowym, z zachowaniem praw osoby, która tych zmian dokonała; 3) rozpowszechniania, w tym użyczenia lub najmu, programu komputerowego lub jego kopii.

Dla porównania warto przytoczyć art. 4 dyrektywy 2009/24/WE, określający czynności zastrzeżone (restricted acts). Przepis art. 4 ust. 1 stanowi, że z zastrzeżeniem przepisów art. 5 i 6 , prawa wyłączne uprawnionego, w rozumieniu art. 2 , obejmuja prawo do wykonywania lub zezwalania na: a) trwałe lub czasowe powielanie (reproduction) programu komputerowego jakimikolwiek środkami i w jakiejkolwiek formie, częściowo lub w całości. W zakresie, w jakim ładowanie (loading), wyświetlanie (displaying), uruchamianie (running), transmitowanie (transmission) lub przechowywanie (storage) programu komputerowego wymaga takiego powielenia, takie czynności wymagają uzyskania zezwolenia uprawnionego; b) translację (translation), adaptację (adaptation), porządkowanie (arrangement) i jakiekolwiek inne modyfikacje (alteration) programu komputerowego i powielenie wyników tych działań bez uszczerbku dla praw osoby, która modyfikuje program; c) jakąkolwiek formę publicznej dystrybucji (any form of distribution to the public), włącznie $\mathrm{z}$ wypożyczeniem oryginalnego programu komputerowego lub jego kopii. W art. 4 ust. 2 dyrektywy postanowiono, że pierwsza sprzedaż na terytorium Wspólnoty kopii programu komputerowego przez uprawnionego lub za jego zgodą wyczerpuje prawo dystrybucji na terytorium Wspólnoty tej kopii, z wyjątkiem prawa do kontroli dalszych wypożyczeń programu lub jego kopii.

W związku z polską wersją językową art. 4 ust. 1 lit. c i ust. 2 dyrektywy 2009/24/WE należy zaznaczyć, że użycie w tych przepisach wyrazu „wypożyczenie" nie jest właściwe. Chodzi bowiem o wynajmowanie (rental), tj. odpłatne oddanie do korzystania, które stanowi przeciwieństwo „użyczenia” (lending), tj. nieodpłatnego oddania do korzystania. W tym kontekście wskazać trzeba ponadto na błąd w polskiej wersji językowej motywu 12 preambuły dyrektywy, w którym stwierdza się, że do celów niniejszej dyrektywy, pojęcie „wypożyczenia" oznacza umożliwienie korzystania przez określony czas, w celach niedo- 
chodowych, z programu komputerowego lub jego kopii. Tymczasem, jak wynika z angielskiej wersji tego postanowienia, chodzi o „cele dochodowe” (for profitmaking purposes), gdyż takie cele zakłada „najem” (rental) ${ }^{34}$. Również w zdaniu drugim motywu 12 preambuły użyto w polskiej wersji językowej niewłaściwego zwrotu „wypożyczanie do użytku publicznego”, gdyż w istocie chodzi o „publiczne użyczenie" (public lending).

\section{OGRANICZENIA AUTORSKICH PRAW MAJĄTKOWYCH DO PROGRAMU KOMPUTEROWEGO}

Przyznając podmiotowi uprawnionemu określony wyżej (art. 74 ust. 4 pr.aut.) zakres wyłączności, zarówno dyrektywa 91/250/EWG (obecnie: 2009/24/WE), jak i oparte na niej przepisy polskiego pr.aut. przewidują wyjątki od tej wyłaczności (ograniczenia praw autorskich). W dyrektywie sa one zawarte w art. 5 i sa określone jako „wyjątki od czynności zastrzeżonych” (exceptions to the restricted acts), a ponadto jeden $\mathrm{z}$ nich został ujęty $\mathrm{w}$ formie zezwolenia na dekompilację (art. 6). W polskiej ustawie są one uregulowane w art. 75 pr.aut.

\section{Ustawowe zezwolenie na korzystanie z programu komputerowego, zgodnie z jego przeznaczeniem, przez legalnego użytkownika}

Zgodnie z art. 75 ust. 1 pr.aut., jeżeli umowa nie stanowi inaczej, czynności wymienione w art. 74 ust. 4 pkt 1 i 2 nie wymagają zgody uprawnionego, jeżeli są niezbędne do korzystania z programu komputerowego zgodnie z jego przeznaczeniem, w tym do poprawiania błędów przez osobę, która legalnie weszła w jego posiadanie. Dla porównania, art. 5 ust. 1 dyrektywy 2009/24/WE stanowi, że w braku szczególnych przepisów umownych czynności określone w art. 4 ust. 1 lit. a i b nie wymagają zezwolenia uprawnionego, jeśli są konieczne do użycia programu przez uprawnionego nabywcę (lawful acquirer) zgodnie z zamierzonym celem (intended purpose), włącznie z poprawianiem błędów.

\section{Ustawowe zezwolenie na wykonanie kopii zapasowej}

Według art. 75 ust. 2 pkt 1 pr.aut. nie wymaga zezwolenia uprawnionego sporządzenie kopii zapasowej, jeżeli jest to niezbędne do korzystania z programu komputerowego. W dalszym ciagu przepis zastrzega, że jeżeli umowa nie stanowi inaczej, kopia ta nie może być używana równocześnie z programem komputerowym. Dla porównania, art. 5 ust. 2 dyrektywy 2009/24/WE stanowi, że sporządzenie kopii zapasowej (back-up copy) przez osobę mająca prawo do używania programu komputerowego nie może być umownie zabronione w zakresie, w jakim jest to konieczne do takiego używania.

${ }^{34}$ Omawiany fragment motywu 12 preambuły w wersji angielskiej brzmi: „For the purposes of this Directive, the term 'rental' means the making available for use, for a limited period of time and for profit-making purposes, of a computer program or a copy thereof". 


\section{Ustawowe zezwolenie na obserwowanie, badanie i testowanie funkcjonowania programu komputerowego}

Zgodnie z art. 75 ust. 2 pkt 2 pr.aut. nie wymaga zezwolenia uprawnionego obserwowanie, badanie i testowanie funkcjonowania programu komputerowego w celu poznania jego idei i zasad przez osobę posiadajacca prawo korzystania z egzemplarza programu komputerowego, jeżeli, będąc do tych czynności upoważniona, dokonuje ona tego w trakcie wprowadzania, wyświetlania, stosowania, przekazywania lub przechowywania programu komputerowego. Dla porównania, art. 5 ust. 3 dyrektywy 2009/24/WE stanowi, że osoba mająca prawo do używania kopii programu komputerowego jest upoważniona, bez zezwolenia uprawnionego, do obserwowania (observe), badania (study) lub testowania (test) funkcjonowania programu w celu ustalenia koncepcji (ideas) i zasad (principles), na których opiera się każdy z elementów programu, jeżeli robi to podczas wykonywania czynności ładowania (loading), wyświetlania (displaying), uruchamiania (running), transmitowania (transmitting) lub przechowywania (storing) programu, w stosunku do którego jest uprawniona.

Wykładni przytoczonego wyżej przepisu dyrektywy (art. 5 ust. 3) dokonał Trybunał Sprawiedliwości we wspomnianym wyżej orzeczeniu w sprawie C-406/10 - SAS Institute Inc. Zdaniem Trybunału przepis ten należy interpretować w ten sposób, że osoba, która uzyskała kopię programu komputerowego na podstawie licencji, jest upoważniona bez zezwolenia podmiotu prawa autorskiego do tego programu do obserwowania, badania lub testowania funkcjonowanie tego programu w celu ustalenia koncepcji i zasad, na których opiera się każdy z elementów wspomnianego programu, gdy dokonuje czynności objętych tą licencją oraz ładowania i uruchamiania koniecznego do używania programu komputerowego, pod warunkiem że osoba ta nie narusza praw wyłącznych podmiotu prawa autorskiego do tego programu.

\section{Ustawowe zezwolenie na dekompilację}

Według art. 75 ust. 2 pkt 3 pr.aut. nie wymaga zezwolenia uprawnionego zwielokrotnianie kodu lub tłumaczenie jego formy w rozumieniu art. 74 ust. 4 pkt 1 i 2 , jeżeli jest to niezbędne do uzyskania informacji koniecznych do osiągnięcia współdziałania niezależnie stworzonego programu komputerowego z innymi programami komputerowymi, o ile zostaną spełnione następujące warunki: a) czynności te dokonywane sa przez licencjobiorcę lub inną osobę uprawnioną do korzystania z egzemplarza programu komputerowego bądź przez inną osobę działająca na ich rzecz, b) informacje niezbędne do osiagnięcia współdziałania nie były uprzednio łatwo dostępne dla osób, o których mowa pod lit. a, c) czynności te odnoszą się do tych części oryginalnego programu komputerowego, które są niezbędne do osiagnięcia współdziałania ${ }^{35}$.

35 Dla porównania, art. 6 ust. 1 dyrektywy 2009/24/WE stanowi: Zezwolenie uprawnionego nie jest wymagane, jeśli powielanie kodu i translacja jego formy w rozumieniu art. 4 ust. 1 lit. a i b, jest niezbędne do otrzymania informacji koniecznych do osiągnięcia interoperacyjności niezależnie 
Jak stanowi art. 75 ust. 3 pr. aut. informacje, o których mowa w ust. 2 pkt 3, nie mogą być: 1) wykorzystane do innych celów niż osiagnięcie współdziałania niezależnie stworzonego programu komputerowego; 2) przekazane innym osobom, chyba że jest to niezbędne do osiagnięcia współdziałania niezależnie stworzonego programu komputerowego; 3) wykorzystane do rozwijania, wytwarzania lub wprowadzania do obrotu programu komputerowego o istotnie podobnej formie wyrażenia lub do innych czynności naruszających prawa autorskie ${ }^{36}$.

W związku z omawianym zezwoleniem na podkreślenie zasługuje jego gospodarcza doniosłość, której przedstawienie wymaga najpierw wyjaśnienia pojęcia dekompilacji. Zabieg ten obejmuje czynności polegające na zwielokrotnieniu kodu programu i tłumaczeniu jego formy ${ }^{37}$, a więc czynności, które sa objęte zakresem wyłączności przysługującej podmiotowi praw autorskich (art. 74 ust. 4 pkt 1 i 2 pr.aut.). Ograniczenie praw autorskich przewidziane w art. 75 ust. 2 pkt 3 i ust. 3 pr.aut. oznacza, że nie wymaga zezwolenia uprawnionego zwielokrotnianie kodu lub tłumaczenie jego formy, w rozumieniu art. 74 ust. 4 pkt 1 i 2 pr.aut., jeżeli jest to niezbędne do uzyskania informacji koniecznych do osiagnięcia współdziałania niezależnie stworzonego programu komputerowego z innymi programami (pod dalszymi warunkami). W zabiegach określanych mianem dekompilacji chodzi o uzyskanie dostępu do niechronionych elementów programu, tj. idei i zasad. Szczególnie istotny jest dostęp do idei i zasad będących podstawa interfejsów (interfaces), określonych w art. 74 ust. 2 pr.aut. jako „łacza”. Sa to części programu umożliwiające jego połączenie i współpracę z innymi elementami systemu komputerowego (z innym programem lub sprzętem) ${ }^{38}$. Brak zezwo-

stworzonego programu komputerowego z innymi programami, z zastrzeżeniem spełnienia następujących warunków: a) czynności te są wykonywane przez licencjobiorcę lub osobę mająca prawo do używania kopii programu, lub upoważnioną osobę działającą w ich imieniu, b) informacje konieczne do osiagnięcia interoperacyjności nie były uprzednio łatwo dostępne dla osób określonych w lit. a), oraz c) czynności te są ograniczone do tych części oryginalnego programu, które są niezbędne dla osiągnięcia interoperacyjności.

${ }^{36}$ Dla porównania, art. 6 ust. 2 dyrektywy 2009/24/WE stanowi: Przepisy ust. 1 nie upoważniaja do tego, aby informacje uzyskane na ich podstawie były: a) wykorzystane do celów innych niż osiąnięcie interoperacyjności niezależnie od siebie stworzonych programów komputerowych; b) przekazywane osobom trzecim, z wyjątkiem kiedy sąkonieczne dlainteroperacyjności stworzonego niezależnie programu komputerowego; c) wykorzystane w celu rozwijania, produkcji lub obrotu programami komputerowymi znacznie podobnymi w swoim wyrazie lub do jakichkolwiek innych czynności naruszających prawo autorskie.

37 Zwrot „tłumaczenie formy kodu” stanowi przekład wyrażenia użytego w dyrektywie 91/250/ EWG (reproduction of the code and translation of its form). Chodzi o odróżnienie tłumaczenia kodu programu (na inny język programowania) od przekształcenia (konwersji) kodu z jednej formy wyrażenia na inna, tj. np. z kodu wynikowego (maszynowego) do postaci źródłowej czytelnej dla człowieka.

38 Zob. motyw 10 dyrektywy 2009/24/WE. Chodzi również o tzw. graficzne interfejsy użytkownika (graphic user interface), określane także jako look and feel. Na temat tej kategorii interfejsów zob. powołany wyżej wyrok Trybunału Sprawiedliwości w sprawie C-393/09 - Bezpečnostni softwarová asociace. W opinii rzecznika generalnego Y. Bota z 14 października 2010 r., poprzedzającej wydanie tego wyroku, czytamy w pkt 56: „Graficzny interfejs użytkownika, nazywany potocznie »look and feel«, pozwala [...] na komunikację między programem a użytkownikiem. Sa to na przykład ikony i symbole widoczne na monitorze, okna czy też menu rozwijane. Umożliwia on interakcję między programem a użytkownikiem. Ta interakcja może polegać na zwykłym przepływie informacji, ale może także umożliwić użytkownikowi przekazywanie do programu 
lenia na dekompilację byłby równoznaczny z ustanowieniem monopolu na idee i zasady zawarte $\mathrm{w}$ programie, a więc elementy niepodlegające ochronie prawnoautorskiej. Wykluczałoby to wytwarzanie programów zdolnych do współpracy (interoperacyjnych) z istniejacym oprogramowaniem i hamowałoby postęp informatyki oraz rozwój technologii opartych na rozwiązaniach informatycznych.

Dopuszczalny zakres dekompilacji (określanej niekiedy jako reverse engineering) był najbardziej kontrowersyjnym problemem w trakcie prac nad dyrektywa 91/250/EWG i był rozważany w kontekście reguł ochrony konkurencji. Udało się uzyskać kompromis polegający na zrównoważeniu interesów liderów rynkowych oraz innych wytwórców oprogramowania, zwłaszcza małych i średnich przedsiębiorców, którzy - pozbawieni dostępu do informacji o interfejsach już rozpowszechnionych programów - nie mają szans wejścia na rynek ze swoimi produktami. Z jednej strony chodziło o zagwarantowanie podmiotowi uprawnionemu klasycznych uprawnień prawnoautorskich, z drugiej - o zapobieżenie sytuacji, w której monopol prawnoautorski faktycznie obejmowałby niechronione elementy i utrudniał konkurencję, blokując wytwarzanie programów kompatybilnych.

Prawne warunki dopuszczalności dekompilacji są określone w dwóch przepisach: art. 75 ust. 2 pkt 3 oraz art. 75 ust. 3 pr.aut. Przepisy te należy interpretować łącznie, gdyż dotyczą one tego samego zezwolenia i łącznie odzwierciedlaja treść art. 6 dyrektywy 2009/24/WE. Szczególnie istotne znaczenie ma wymóg, aby czynności objęte omawianym zezwoleniem (zwielokrotnianie kodu lub tłumaczenie jego formy w rozumieniu art. 74 ust. 4 pkt 1 i 2) były „niezbędne do uzyskania informacji koniecznych do osiagnięcia współdziałania niezależnie stworzonego programu komputerowego z innymi programami komputerowymi”. Pojęcie „interoperacyjności” (interoperability) zostało wyjaśnione w motywie 10 preambuły dyrektywy 2009/24/WE. Wychodzi się z określenia funkcji programu, którą jest komunikowanie się i wspólne funkcjonowanie z innymi częściami systemu komputerowego i z użytkownikami. W tym celu jak stwierdza się dalej-wymagane są logiczne i, tam gdzie to właściwe, fizyczne wzajemne połączenia (interconnection) i wzajemne oddziaływanie (interaction), tak aby pozwolić wszystkim elementom oprogramowania i sprzętu komputerowego na funkcjonowanie $\mathrm{z}$ innym oprogramowaniem, sprzętem komputerowym i użytkownikami we wszelkich formach działania, do jakich są przeznaczone. Części programu umożliwiające takie wzajemne połączenia i wzajemne oddziaływanie między elementami oprogramowania i sprzętu komputerowego są ogólnie znane pod nazwą „interfejsów”. To funkcjonalne wzajemne połączenie i wzajemne oddziaływanie jest ogólnie znane pod nazwą „interoperacyjności”; może być ona zdefiniowana jako zdolność do wymiany informacji oraz wzajemnego wykorzystania informacji już wymienionych ${ }^{39}$.

\footnotetext{
komputerowego instrukcji za pomoca poleceń. Ma to na przykład miejsce w przypadku pliku zaznaczonego myszką i przesuniętego do kosza lub poleceń »kopiuj« i »wklej« w edytorze tekstu”.

${ }^{39} \mathrm{~W}$ wersji angielskiej końcowa część motywu 10 preambuły dyrektywy 2009/24/WE brzmi: „This functional interconnection and interaction is generally known as 'interoperability'; such interoperability can be defined as the ability to exchange information and mutually to use the information which has been exchanged".
} 
Podkreślić należy, że zezwolenia przewidziane w art. 75 ust. 2 i 3 pr.aut. nie moga być wyłączone ani ograniczone w drodze umowy stron (np. umowy licencyjnej). Przepisy te mają charakter bezwzględnie wiążący (ius cogens), a ich naruszenie powoduje nieważność postanowień umownych sprzecznych z tymi przepisami. Jak bowiem stanowi art. 76 pr.aut., postanowienia umów sprzeczne z art. 75 ust. 2 i 3 są nieważne. Należy dodać, że sankcja nieważności została przejęta z art. 9 ust. 1 zdanie drugie dyrektywy 91/250/EWG (obecnie: art. 8 zd. 2 dyrektywy 2009/24/WE), według którego jakiekolwiek postanowienia umowne sprzeczne z art. 6 lub z wyjątkami przewidzianymi w art. 5 ust. 2 i 3 są nieważne.

Ustawodawca polski, przejmując regulację dekompilacji z dyrektywy 91/250/ EWG (obecnie: 2009/24/WE), nie powtórzył art. 6 ust. 3 dyrektywy, który - powołując się na Konwencję berneńską - wyraża zasadę, że zezwolenie na dekompilację nie może być interpretowane w sposób, który naruszałby słuszne interesy podmiotu uprawnionego lub pozostawałby $\mathrm{w}$ sprzeczności $\mathrm{z}$ normalnym korzystaniem z programu ${ }^{40}$. Chodzi o respektowanie art. 9 ust. 2 Konwencji berneńskiej ${ }^{41}$, która pod powyższymi warunkami zezwala państwom stronom na ustanowienie zezwoleń na zwielokrotnienie utworu (tzw. trójstopniowy test). Pominięcie tej regulacji w przepisach rozdziału 7 polskiej ustawy nie jest błędem. Skoro bowiem zezwolenie na dekompilację jest szczególną postacią ograniczenia prawa autorskiego (dozwolonego użytku), to pełne zastosowanie znajduje zasada ogólna, wyrażona w art. 35 pr.aut., według której dozwolony użytek nie może naruszać normalnego korzystania z utworu lub godzić w słuszne interesy twórcy.

Z kolei brak w art. 74 ust. 4 pkt 3 pr.aut. regulacji wyczerpania (exhaustion) prawa wprowadzania do obrotu (distribution right), zawartej w art. 4 ust. 2 dyrektywy 2009/24/WE, jest uzasadniony w świetle ogólnej regulacji wyczerpania, zawartej w art. 51 ust. 3 pr.aut. Według tego przepisu „wprowadzenie do obrotu oryginału albo egzemplarza utworu na terytorium Europejskiego Obszaru Gospodarczego wyczerpuje prawo do zezwalania na dalszy obrót takim egzemplarzem na terytorium Rzeczypospolitej Polskiej, z wyjątkiem jego najmu lub użyczenia”.

Zagadnienia związane z wykładnią art. 4 ust. 2 dyrektywy 2009/24/WE dotyczącego wyczerpania prawa dystrybucji (wprowadzania do obrotu) kopii programu komputerowego były przedmiotem wyroku Trybunału Sprawiedliwości z 3 lipca 2012 r. w sprawie C-128/11 - UsedSoft GmbH v. Oracle International Corp. $^{42}$ Zdaniem Trybunału, wykładni art. 4 ust. 2 dyrektywy należy dokony-

${ }^{40}$ Art. 6 ust. 3 dyrektywy 2009/24/WE stanowi: „Zgodnie z przepisami konwencji berneńskiej o ochronie dzieł literackich i artystycznych, niniejszy artykuł nie może być interpretowany tak, aby możliwe było jego stosowanie w sposób, który bez uzasadnienia narusza słuszne interesy uprawnionego lub pozostaje w sprzeczności z normalnym korzystaniem z programu komputerowego".

${ }^{41}$ Art. 9 ust. 2 Konwencji berneńskiej stanowi: „Ustawodawstwu państw należących do Związu zastrzega się możność zezwolenia na reprodukcję tych dzieł w pewnych szczególnych wypadkach, pod warunkiem że reprodukcja ta nie wyrządzi szkody normalnemu korzystaniu z dzieła ani nie przyniesie nieuzasadnionego uszczerbku prawowitym interesom autora”.

${ }^{42}$ Dz. Urz. UE C 287 z 22 września 2012 r., s. 10. Wyrok został wydany w odpowiedzi na pytania prejudycjalne niemieckiego Federalnego Sądu Najwyższego (BGH) sformułowane w orzecze- 
wać w taki sposób, że prawo do rozpowszechniania kopii programu komputerowego zostaje wyczerpane, jeśli podmiot praw autorskich, który zezwolił, choćby i nieodpłatnie, na pobranie tej kopii z Internetu na nośnik danych, również przyznał, w zamian za zapłatę ceny mającej umożliwić mu uzyskanie wynagrodzenia odpowiadającego wartości gospodarczej kopii dzieła, którego jest on właścicielem, prawo do nieograniczonego w czasie korzystania z tej kopii. Szczególne znaczenie ma dokonana przez Trybunał wykładnia art. 4 ust. 2 oraz art. 5 ust. 1 dyrektywy 2009/24/WE, zgodnie z którą w przypadku odsprzedaży licencji na korzystanie obejmującej odsprzedaż kopii programu komputerowego pobranej ze strony internetowej podmiotu praw autorskich, licencji, która została początkowo przyznana pierwszemu nabywcy przez ten podmiot praw autorskich na czas nieograniczony i w zamian za zapłatę ceny mającej mu umożliwić uzyskanie wynagrodzenia odpowiadającego wartości gospodarczej kopii jego dzieła, drugi nabywca tej licencji, podobnie jak każdy następny, mogą się powołać na przewidziane w art. 4 ust. 2 dyrektywy wyczerpanie prawa do rozpowszechniania i co za tym idzie - moga zostać uznani za uprawnionych nabywców kopii programu komputerowego w rozumieniu art. 5 ust. 1 dyrektywy i korzystać z przewidzianego w tym przepisie prawa do zwielokrotniania ${ }^{43}$.

Warto zaznaczyć, że wydając wyrok w sprawie C-128/11 - UsedSoft GmbH, Trybunał Sprawiedliwości nie w pełni zgodził się z opinią rzecznika generalnego Y. Bota z 24 kwietnia 2012 r. Istotna jest zwłaszcza różnica dotycząca tezy nr 2, gdyż rzecznik generalny zaproponował odmienną odpowiedź na pytanie dotyczące wykładni art. 4 ust. 2 i art. 5 ust. 1 dyrektywy 2009/24/WE. Według tej propozycji w przypadku odsprzedaży prawa korzystania z kopii programu komputerowego drugi nabywca nie mógłby powoływać się na zasadę wyczerpania prawa do rozpowszechniania tej kopii po to, aby zwielokrotnić program przez sporządzenie nowej kopii, nawet gdy pierwszy nabywca usunął swoja kopię programu albo przestał z niej korzystać. Mając na względzie gospodarczą doniosłość wyczerpania prawa dystrybucji (wprowadzania do obrotu) programu komputerowego, stanowisko Trybunału należy uznać za trafne ${ }^{44}$.

niu z 3 lutego 2011 r., I ZR 129/08 (www.bundesgerichtshof.de). Pytania złożone w TS 14 marca 2011 r. (Dz. Urz. UE C 194 z 2 lipca 2011 r., s. 8) brzmiały: „1) Czy ten, kto może powołać się na wyczerpanie prawa do dystrybucji kopii programu komputerowego, jest "uprawnionym nabywcą" w rozumieniu art. 5 ust. 1 dyrektywy 2009/24/WE?; 2) W razie udzielenia odpowiedzi twierdzącej na pytanie pierwsze: czy prawo do dystrybucji kopii programu komputerowego wyczerpuje zgodnie z art. 4 ust. 2 in initio dyrektywy 2009/24/WE sporządzenie przez nabywcę kopii poprzez ściagnięcie programu z Internetu na nośnik danych za zgodą uprawnionego?; 3) W razie udzielenia odpowiedzi twierdzącej również na drugie pytanie: czy również ten, kto nabył »używanąu licencję na oprogramowanie, może w odniesieniu do sporządzenia kopii programu powołać się "jako uprawniony nabywca" na wyczerpanie prawa do dystrybucji kopii programu komputerowego sporządzonej przez pierwszego nabywcę poprzez ściagnięcie programu z Internetu na nośnik danych za zgodą uprawnionego, jeżeli pierwszy nabywca usunął swoją kopię programu lub jej nie używa?".

${ }^{43} \mathrm{~W}$ związku z tym rozstrzygnięciem zob. orzeczenie BGH z 17 lipca 2013 r., I ZR 129/08 UsedSoft II (BGH uchylił wyrok sądu w Monachium i przekazał sprawę temu sądowi do ponownego rozpoznania).

${ }^{44}$ Natomiast zachodzi zbieżność stanowiska TS i propozycji rzecznika generalnego w zakresie pierwszego pytania prejudycjalnego. Zaproponowana przez rzecznika generalnego odpowiedź 


\title{
VI. AUTORSKIE PRAWA OSOBISTE TWÓRCÓW PROGRAMÓW KOMPUTEROWYCH
}

Autorskie prawa osobiste chronią nieograniczoną w czasie i niepodlegajacca zrzeczeniu się lub zbyciu więź twórcy z utworem (art. 16 pr.aut.). W odniesieniu do twórców programów komputerowych katalog autorskich praw osobistych jest ograniczony. Na podstawie art. 77 pr.aut. twórcom programów nie przysługują: a) prawo do nienaruszalności treści i formy utworu oraz jego rzetelnego wykorzystania, b) prawo do decydowania o pierwszym udostępnieniu utworu publiczności, c) prawo do nadzoru nad sposobem korzystania z utworu. Spośród praw osobistych wymienionych w art. 16 pr.aut. twórcom programów przysługują tylko prawa do autorstwa utworu oraz do oznaczenia utworu swoim nazwiskiem lub pseudonimem albo do udostępniania go anonimowo.

prof. dr hab. Aurelia Nowicka

Uniwersytet im. Adama Mickiewicza w Poznaniu

aunow@amu.edu.pl

\author{
COPYRIGHT PROTECTION OF COMPUTER PROGRAMS \\ - POLISH REGULATION AND ITS EUROPEAN UNION MODEL \\ IN LIGHT OF JUDGMENTS OF THE COURT OF JUSTICE
}

Summary

The aim of this paper is to analyse the main aspects of copyright protection of computer programs. First the authoress presents the legal and economic circumstances of this model of computer programs protection, which led to the adoption of Directive 91/250/EEC (now in its consolidated version contained in Directive 2009/24/EC). Next she analyses the provisions of the Polish copyright law, pointing out that the primary version of Polish copyright law of 1994 was based on the provisions of the above mentioned EEC Directive. Hence Polish copyright law regards a computer program as work defined in relevant provisions of copyright law. Consequently, special focus in the paper is put of the subject and the scope of copyright protection. Further in the paper, the economic rights to a computer program are characterised, followed by subsequent restrictions of these rights, and decompilation in particular. The overall analysis includes legal interpretation of the provisions of Directive 91/250/EEC (or Directive 2009/24/EC of the CJEU in the following judgments: C-393/09 - Bezpečnostni softwarová asociace, C-406/10 SAS - Institute Inc. and C-128/11 - UsedSoft GmbH.

\footnotetext{
brzmiała: „Wykładni art. 4 ust. 2 dyrektywy 2009/24/WE [...] należy dokonywać w ten sposób, że prawo do rozpowszechniania kopii programu komputerowego zostaje wyczerpane, jeśli podmiot tego prawa, który zezwolił na pobranie z Internetu tej kopii i zapisanie jej na nośniku danych, przyznał również za wynagrodzeniem prawo korzystania z tej kopii na czas nieokreślony. Sprzedażą w rozumieniu tego przepisu jest bowiem wszelkie udostępnienie w Unii, w jakiejkolwiek formie i jakimikolwiek środkami, programu komputerowego w celu nieograniczonego w czasie korzystania z niego w zamian za zapłatę ustalonej ceny".
} 
